\title{
Entrapped White Matter Present
}

National Cancer Institute

\section{Source}

National Cancer Institute. Entrapped White Matter Present. NCI Thesaurus. Code C96353.

A morphologic finding that refers to the presence of ectopic white matter in a tissue sample. 